\title{
TURYSTYKA ZRÓWNOWAŻONA NA OBSZARACH PRZYRODNICZO CENNYCH: KONTEKSTY TEORETYCZNE - STRATEGIE - ZASTOSOWANIA ${ }^{1}$
}

\section{Wprowadzenie i zagadnienia metodologiczne}

Walory i zasoby przyrodnicze są uznawane za jedne z podstawowych czynników decydujących o atrakcyjności turystycznej danego terenu. Liczne przykłady zarówno europejskie, jak i pozaeuropejskie dowodza, że obszary przyrodniczo cenne, mimo że powinny podlegać ochronie, stanowią zazwyczaj miejsca intensywnej eksploracji turystycznej. Dotyczy to nie tylko terenów objętych ochroną na mocy prawa, ale także obszarów przyrodniczo cennych, definiowanych jako te, „których wartości [...] służyć mogą zaspokojeniu potrzeb wypoczynkowych, turystycznych, zdrowotnych, kulturalnych, estetycznych, naukowych i innych" (Jalinik, 2009, s. 88), a jednocześnie pozostają poza oficjalnym systemem ochrony. Można w tym dostrzec pewną sprzeczność: obszary o cennych wartościach środowiskowych ze względu na niezdegradowane walory, które powinny podlegać ochronie, służą zaspokajaniu rozmaitych potrzeb społecznych, gospodarczych, kulturowych i innych. W przytoczonej definicji zasygnalizowano jeszcze jedną kwestię - obszary chronione, wykorzystywane m.in. do celów turystycznych, są miejscem współistnienia i oddziaływania różnych grup interesu. Warto w tym miejscu wskazać na znaczenie koncepcji rozwoju zrównoważonego, która w podobnych,

${ }^{1} \mathrm{~W}$ artykule zostały zaprezentowane dane i informacje uzyskane na potrzeby projektu Innowacje w turystyce i rekreacyjnej aktywności fizycznej w paradygmacie zrównoważonego rozwoju: implementacja - percepcja - efekty, finansowanego w ramach działalności Społeczno-Humanistycznej Szkoły Badań Kultury Fizycznej Akademii Wychowania Fizycznego J. Piłsudskiego w Warszawie. 
bardzo złożonych sytuacjach znajduje szerokie zastosowanie tak na poziomie ideowym, jak i operacyjnym. Zgodnie z tą koncepcją konieczne jest, w dużym uproszczeniu, poszukiwanie kompromisów pomiędzy wszystkimi podmiotami występującymi na danym obszarze oraz projektowanie rozwoju z uwzględnieniem dalekiego horyzontu czasowego. Specyfika każdego terenu wymaga jednak indywidualnej i precyzyjnej diagnozy uwarunkowań, potrzeb, perspektyw rozwoju oraz wypracowania specyficznych narzędzi i scenariuszy postępowania.

Przedstawiane w dalszej części artykułu wyniki badań własnych, ze względu na wieloaspektowość poruszanych zagadnień, odwołują się do różnych źródeł danych i informacji. Wśród najważniejszych można wymienić:

- literaturę podmiotu oraz dokumenty i opracowania dostępne m.in. na oficjalnych stronach internetowych poświęconych obszarom chronionym wybranych krajów oraz materiały informacyjne parków narodowych (analiza danych zastanych),

- informacje uzyskane $\mathrm{w}$ trakcie rozmów prowadzonych z pracownikami parków narodowych (wywiady swobodne z elementami wywiadu pogłębionego),

- obserwację uczestniczącą.

Prezentowane wyniki badań odnoszą się do dwóch krajów:

- Portugalii, w której obowiązuje stosunkowo słabo rozbudowany system ochrony przyrody;

- Stanów Zjednoczonych Ameryki Północnej (USA), gdzie stworzono rozwinięty system ochrony przyrody, a obszary przyrodniczo cenne należą do najliczniej odwiedzanych na świecie.

Ze względu na dużą różnorodność, wynikającą z uwarunkowań przyrodniczych, geograficznych, przestrzennych, a także organizacyjnych czy politycznych wymienionych krajów, w zaprezentowanym w dalszej części pracy katalogu rozwiązań wymieniono wiele działań, stanowiących realizację założeń rozwoju zrównoważonego.

\section{Turystyka zrównoważona na obszarach chronionych - konteksty teoretyczne}

Jak już zauważono, obszary atrakcyjne turystycznie stanowią zazwyczaj miejsce współwystępowania rozmaitych grup interesu. Identyfikacja ich oczekiwań - pod kątem koncepcji rozwoju zrównoważonego - powinna 
stanowić punkt wyjścia do dalszych działań związanych z projektowaniem rozwoju i realizacją konkretnych planów. Wśród grup interesu najczęściej występujących na obszarach turystycznych wymienić można (Kozak, 2009; Majdak, 2019):

- społeczność lokalną, która wchodzi w różne interakcje (pozytywne i negatywne) z turystami;

- lokalną władzę, kreującą określoną politykę rozwojowa, a także posiadającą instrumenty, dzięki którym może wpływać na rozmaite parametry ruchu turystycznego;

- przedstawicieli lokalnych stowarzyszeń i zrzeszeń, podejmujących inicjatywy związane z funkcjonowaniem miejscowości i rozwojem funkcji turystycznych;

- prywatnych i publicznych dysponentów oraz właścicieli atrakcji turystycznych, którzy decydują o formule udostępniania atrakcji turystycznych;

- przedsiębiorców, właścicieli obiektów noclegowych, handlowych, gastronomicznych oraz inne podmioty prowadzące działalność komercyjna:

- osoby reprezentujące interesy środowiska przyrodniczego;

- turystów jako bezpośrednich odbiorców kierowanej do nich oferty, decydujących o sukcesie lub porażce podejmowanych działań.

Interesy wymienionych wyżej grup wzajemnie się przenikaja, co niejednokrotnie prowadzi do pojawiania się sytuacji konfliktowych. W podobnych, złożonych i wymagających długofalowego planowania okolicznościach koncepcja rozwoju zrównoważonego znajduje zastosowanie szczególne. Zakłada bowiem m.in. konieczność poszukiwania kompromisów pomiędzy funkcjonującymi na danym obszarze grupami interesu (Kassenberg, 2007). Teoretycy tego zagadnienia wymieniają także następujące elementy koncepcji: promowanie jakości (świadczonych usług, oferowanego produktu itd.), integrację działalności turystycznej z celami ochrony przyrody, zapewnianie poczucia bezpieczeństwa turystom i gospodarzom (społeczności lokalnej), konieczność ochrony środowiska przyrodniczego, społecznego i historyczno-kulturowego (przeciwdziałanie degradacji, ochrona konserwatorska), kształtowanie nowych postaw wśród organizatorów ruchu turystycznego i turystów (Coccossis, Parpairis, 2000; Gołembski, 2002).

W podobny sposób turystykę zrównoważoną interpretuje Jędrzejczyk (1995, za: Kowalczyk, 2010), wskazująca podstawowe zasady, na których opiera się koncepcja. Wśród nich autorka wymienia: 
- zasadę ładu gospodarczego, oznaczającego konieczność zachowania określonych proporcji między wzrostem tempa zasobochłonności gospodarki turystycznej a szybkością odtworzenie zasobów środowiska; - zasadę efektywności społeczno-ekonomicznej gospodarki turystycznej;

- konieczność ochrony i oszczędności zasobów;

- zasadę wzajemnych korzyści wszystkich grup interesu, funkcjonujących na danym obszarze.

Wymienione wskazania są obecne także w dokumentach i strategiach opracowanych przez organizacje odpowiedzialne za ochronę obszarów przyrodniczo cennych w poszczególnych krajach. W dokumentach stworzonych przez National Park Service (amerykańska Służba Parków Narodowych) wielokrotnie wskazuje się na potrzebę integrowania środowiska ludzkiego (cywilizacji) ze środowiskiem naturalnym:

[...] zrównoważone projektowanie powinno używać alternatywnego podejścia do tradycyjnego sposobu planowania. W nowym podejściu do projektowania trzeba uwzględniać wykorzystanie potencjału opartego na zasobach naturalnych i kulturowych lokalnych, regionalnych i globalnych środowisk [...]. Koncepcja zrównoważonego rozwoju [...] zakłada, że cywilizacja ludzka jest integralną częścią świata przyrody i że natura musi być zachowana i utrwalana, jeśli sama wspólnota ludzka chce przetrwać. W zrównoważonym projektowaniu ta idea jest wyrażana poprzez zmiany, które stanowią ilustrację zasad ochrony i zachęcają do stosowania ich w naszym codziennym życiu. [...] (tłum. własne na podstawie: Tefft, Thayer, Thomas, 1993, s. 4-5).

Istotnym elementem wdrażania założeń rozwoju zrównoważonego pozostają dalekie horyzonty czasowe oraz etapowość działań, które znajdują swoje odzwierciedlenie w koncepcji The Limits of Acceptable Change Planning System (LAC), opracowanej przez US Forest Service w 1980 r. $\mathrm{W}$ jednym z opracowań poświęconych programowi czytamy, że:

LAC nie jest koncepcją nową. Jest to jednak ostatni krok w ciągłym dążeniu do poprawy zarządzania dzikimi obszarami rekreacji poprzez zdefiniowanie bardziej wyraźnych, wymiernych celów. W dokumencie wskazano dziewięć etapów, niezbędnych do osiągnięcia zamierzonych celów. Wśród nich można wymienić: 1 . Identyfikację problemów, obszarów i zagadnień. 2. Określenie i opis działań alternatywnych. 3. Wybór wskaźników opisujących zasoby i uwarunkowania społeczne. 4. Inwentaryzację istniejących zasobów i opis uwarunkowań społecznych. 5. Określenie standardów dotyczących zasobów i wskaźników społecznych. 6. Określenie alternatywnych rozwiązań odzwierciedlających problemy w odniesieniu do zasobów i uwarunkowań społecznych. 7. Identyfikację działań w przypadku każdej 
możliwości. 8. Ocenę i wybór najkorzystniejszego rozwiązania. 9. Realizację działań i monitorowanie efektów (tłum. własne na podstawie: Stankey, Cole, Lucas, Petersen, Frissell, 1985, s. 3).

Tak pojmowana koncepcja projektowania rozwoju i zarządzania obszarem oznacza dążenie do osiągnięcia

modelu idealnego, który może pojawić się jedynie wtedy, gdy między czterema jej zasadniczymi elementami (środowisko przyrodnicze, turyści, społeczności lokalne, usługodawcy turystyczni) występuje stan równowagi. [...] Na ogół sytuacja przypominająca stan, który można uznać za bliski turystyki zrównoważonej, może zaistnieć tylko wtedy, gdy aktywne elementy układu - czyli: (a) turyści, (b) społeczności lokalne i reprezentujące ich władze oraz (c) osoby prawne i fizyczne świadczące szeroko rozumiane usługi turystyczne i czerpiące z tego tytułu korzyści - wykazują chęć wprowadzania w stosunku do siebie różnego rodzaju ograniczeń (samoograniczeń) (Kowalczyk, 2010, s. 33).

W cytowanych $\mathrm{w}$ tym podrozdziale publikacjach zostały nakreślone ogólne ramy koncepcji rozwoju zrównoważonego w odniesieniu do obszarów chronionych, pełniących funkcje turystyczne. Założenia teoretyczne stanowią punkt wyjścia do opracowywania planów operacyjnych, strategii rozwoju, a także konkretnych działań zmierzających do realizowania koncepcji w praktyce.

\section{Strategie rozwoju zrównoważonego i ich wdrażanie}

Koncepcja rozwoju zrównoważonego stanowi punkt wyjścia wielu programów rozwoju. Jej echa można odnaleźć zarówno w strategiach krajów europejskich, jak i pozaeuropejskich. W tej części tekstu przedstawiono wybrane programy i dokumenty, które zawierają istotne wskazania dotyczące działań praktycznych, służących wprowadzaniu założeń rozwoju zrównoważonego w Portugalii i USA.

\subsection{Portugalia}

Kluczowym dokumentem określającym ramy turystyki zrównoważonej na obszarach chronionych w Portugalii jest Narodowy Program Turystyki Przyrodniczej (Programa Nacional de Turismo de Natureza, PNTN), adresowany m.in. do podmiotów branży turystycznej zainteresowanych prowadzeniem działalności na tego typu terenach. Warunkiem otrzymania stosownego certyfikatu jest spełnienie wielu kryteriów 
z zakresu rozwoju zrównoważonego, ochrony środowiska i dobrych praktyk, a także uczestnictwo podmiotu w co najmniej jednym projekcie ochrony przyrody i różnorodności biologicznej. W tab. 1 w sposób hasłowy zaprezentowano wybrane kryteria (tab. 1).

Tabela 1. Rozwój zrównoważony - wybrane kryteria oceny programu PNTN

\begin{tabular}{|c|c|c|}
\hline Lp. & Kryterium/zagadnienie & Opis/działanie/zalecenia \\
\hline 1 & $\begin{array}{l}\text { Działalność informacyjna } \\
\text { i szkoleniowa }\end{array}$ & $\begin{array}{l}\text { Dostarczanie pracownikom informacji na temat } \\
\text { szkoleń z zakresu ochrony przyrody, zachowań } \\
\text { nieszkodliwych dla środowiska i różnorodności } \\
\text { biologicznej. } \\
\text { Udzielanie informacji na temat realizacji dobrych } \\
\text { praktyk z zakresu rozwoju zrównoważonego i eko- } \\
\text { turystyki w przedsiębiorstwie. }\end{array}$ \\
\hline 2 & $\begin{array}{l}\text { Informacja } \\
\text { o usługach turystycznych }\end{array}$ & $\begin{array}{l}\text { Udostępnianie informacji o usługach, które gwa- } \\
\text { rantują możliwość korzystania z naturalnego dzie- } \\
\text { dzictwa regionu przez klientów (animacja tury- } \\
\text { styczna, zwiedzanie obszarów naturalnych, upra- } \\
\text { wianie sportów na świeżym powietrzu, interpre- } \\
\text { tacja dziedzictwa i ochrona środowiska). }\end{array}$ \\
\hline 3 & Transport publiczny & $\begin{array}{l}\text { Udostępnianie pracownikom i gościom informacji } \\
\text { o funkcjonowaniu transportu publicznego. }\end{array}$ \\
\hline 4 & $\begin{array}{l}\text { Pochodzenie produktów } \\
\text { spożywczych }\end{array}$ & $\begin{array}{l}\text { Udostępnianie klientom informacji o pochodzeniu } \\
\text { i sposobach tworzenia użytych produktów spo- } \\
\text { żywczych. }\end{array}$ \\
\hline 5 & $\begin{array}{l}\text { Utrzymanie terenów } \\
\text { zielonych }\end{array}$ & $\begin{array}{l}\text { Tereny zielone } \mathrm{w} \text { otoczeniu przedsiębiorstwa na- } \\
\text { leży utrzymywać bez użycia pestycydów lub } \\
\text { zgodnie z zasadami rolnictwa ekologicznego. } \\
\text { Kwiaty i ogrody powinny być regularnie podle- } \\
\text { wane przed południem lub po zachodzie słońca } \\
\text { i tylko w regionach, w których występują warunki } \\
\text { regionalne i lokalne uzasadniające to. }\end{array}$ \\
\hline 6 & $\begin{array}{l}\text { Źródło zaopatrzenia } \\
\text { i jakość wody }\end{array}$ & $\begin{array}{l}\text { W przypadku gdy przedsiębiorstwo nie jest pod- } \\
\text { łączone do publicznej sieci dystrybucji wody, } \\
\text { podmiot zapewnia, że eksploatowane źródło } \\
\text { nie powoduje uszczerbku środowiska, a woda } \\
\text { przeznaczona do spożycia jest należycie kontro- } \\
\text { lowana. }\end{array}$ \\
\hline 7 & $\begin{array}{l}\text { Przepływ wody z kranów } \\
\text { i pryszniców }\end{array}$ & $\begin{array}{l}\text { Przepływ wody w kranach i prysznicach nie może } \\
\text { przekraczać } 12 \text { l/min. }\end{array}$ \\
\hline 8 & Utrata wody & $\begin{array}{l}\text { Należy przeszkolić personel przedsiębiorstwa do } \\
\text { monitorowania widocznych strat wody. }\end{array}$ \\
\hline
\end{tabular}




\begin{tabular}{|c|c|c|}
\hline 9 & $\begin{array}{l}\text { Oszczędzanie wody } \\
\text { w łazienkach }\end{array}$ & $\begin{array}{l}\text { Umieszczenie w łazienkach informacji dotyczą- } \\
\text { cych sposobów oszczędzania wody. }\end{array}$ \\
\hline 10 & $\begin{array}{l}\text { Korzystanie } \\
\text { z energii elektrycznej }\end{array}$ & $\begin{array}{l}\text { Jeżeli światła w pokojach hotelowych nie wyłą- } \\
\text { czają się automatycznie, stosowna informacja oraz } \\
\text { prośba o wygaszenie świateł przed opuszczeniem } \\
\text { pokoju powinny być umieszczone w widocznym } \\
\text { miejscu. }\end{array}$ \\
\hline 11 & $\begin{array}{l}\text { Korzystanie z ogrzewania } \\
\text { i klimatyzacji }\end{array}$ & $\begin{array}{l}\text { W przypadku gdy klimatyzatory nie wyłączają się } \\
\text { automatycznie przy otwartych oknach, stosowna } \\
\text { informacja oraz prośba o zamknięcie okien powin- } \\
\text { ny być umieszczone w widocznym miejscu. }\end{array}$ \\
\hline 12 & Zmiana ręczników i pościeli & $\begin{array}{l}\text { Goście powinni być informowani, że - zgodnie } \\
\text { z polityką środowiskową przedsiębiorstwa - po- } \\
\text { ściel i ręczniki są zmieniane tylko na życzenie go- } \\
\text { ści lub zgodnie z wymaganym prawnie minimum. }\end{array}$ \\
\hline 13 & Izolacja okien & $\begin{array}{l}\text { Wszystkie okna powinny mieć stosowny do lokal- } \\
\text { nych uwarunkowań stopień izolacji termicznej } \\
\text { oraz zapewniać odpowiedni poziom izolacji aku- } \\
\text { stycznej. }\end{array}$ \\
\hline 14 & $\begin{array}{l}\text { Efektywność energetyczna } \\
\text { żarówek }\end{array}$ & $\begin{array}{l}\text { Co najmniej } 60 \% \text { wszystkich żarówek w obudo- } \\
\text { wie musi posiadać klasę energetyczną A (zgodnie } \\
\text { z dyrektywą nr 92/75/EWG Parlamentu Europej- } \\
\text { skiego). }\end{array}$ \\
\hline 15 & $\begin{array}{l}\text { Produkty jednorazowego } \\
\text { użytku }\end{array}$ & $\begin{array}{l}\text { Ograniczenie zużycia produktów jednorazowych } \\
\text { (szczególnie filiżanek, talerzy, sztućców). }\end{array}$ \\
\hline 16 & $\begin{array}{l}\text { Stosowanie } \\
\text { środków dezynfekcyjnych }\end{array}$ & $\begin{array}{l}\text { Środki dezynfekcyjne należy stosować, wyłącznie } \\
\text { gdy jest to konieczne, aby spełnić wymogi praw- } \\
\text { ne dotyczące higieny. Personel powinien przejść } \\
\text { szkolenie z zakresu zalecanych dawek detergen- } \\
\text { tów lub środków dezynfekcyjnych. }\end{array}$ \\
\hline 17 & $\begin{array}{l}\text { Dozowanie } \\
\text { środka dezynfekcyjnego } \\
\text { do basenów }\end{array}$ & $\begin{array}{l}\text { Baseny muszą mieć system, który zapewnia sto- } \\
\text { sowanie minimalnej, niezbędnej ilości środka de- } \\
\text { zynfekcyjnego. }\end{array}$ \\
\hline 18 & Czyszczenie mechaniczne & $\begin{array}{l}\text { W przedsiębiorstwie muszą być wdrażane proce- } \\
\text { dury czyszczenia bez środków chemicznych (na } \\
\text { przykład poprzez użycie produktów z mikrofibry } \\
\text { lub innych materiałów niechemicznych). }\end{array}$ \\
\hline 19 & Segregacja odpadów & Personel kontroluje i segreguje odpady. \\
\hline 20 & Odpady niebezpieczne & $\begin{array}{l}\text { Personel przedsiębiorstwa zbiera odpady (tonery, } \\
\text { tusze do druku, urządzenia chłodnicze, baterie, } \\
\text { farmaceutyki) i dba o ich właściwą utylizację. }\end{array}$ \\
\hline
\end{tabular}

Źródło: opracowanie własne na podstawie informacji zawartych na stronie internetowej Programa Nacional de Turismo de Natureza (2017). 
Przestrzeganie wymienionych $\mathrm{w}$ tab. 1 zaleceń wymaga od podmiotów zainteresowanych uzyskaniem licencji podjęcia działań praktycznych o charakterze inżynieryjno-technicznym, gospodarczym, organizacyjnym, edukacyjnym, społecznym.

Odrębnym zagadnieniem pozostaje turystyka zrównoważona na obszarach chronionych, dostępna w ofertach biur turystycznych. Analiza propozycji portugalskich touroperatorów wskazuje, że odwoływanie się do założeń koncepcji stanowi ważny element wizerunku wielu podmiotów. W związku z tym można odnaleźć programy wycieczek realizowanych wyłącznie w małych grupach, przy udziale lokalnych przewodników i usługodawców turystycznych (transport, gastronomia, usługi noclegowe, oferta kulturowa itp.). Ponadto promowana jest aktywność niestanowiąca obciążenia dla środowiska przyrodniczego, redukująca powstawanie odpadów, ukierunkowana na współpracę z lokalną społecznością.

Interesującym przejawem praktycznej działalności portugalskich biur turystycznych jest aktywność związana ze wspieraniem programów służących m.in. ochronie środowiska. Przykładem może być chociażby biuro turystyczne Walk Hike Portugal, które w ramach partnerstwa z Sintrą i Urzędem Miasta Cascais oraz firmą Moon Mountain uczestniczy w programach oczyszczania, konserwacji i ponownego zalesiania parku naturalnego Sintra Sierra, przyczyniając się w ten sposób do zachowania różnorodności biologicznej. Ponadto, jak czytamy na stronie firmy:

[...] bycie $w$ terenie pozwala nam również informować władze o poważnych sytuacjach wymagających szybkiej interwencji. Ostrzeżenia, które przekazaliśmy ratownikowi Cascais w sprawie katastrofy na plaży „Espigão das Ruivas", są tego przykładem. W wyniku naszego alarmu, szybka i skuteczna reakcja ratusza w Cascais pozwoliła na usunięcie prawie dwóch ton śmieci $\mathrm{z}$ tej małej i dzikiej plaży (tłum. własne na podstawie: Sustainable tourism, 2020).

Warto zwrócić uwagę na inicjatywę polegającą na zatrudnianiu osób bezdomnych jako przewodników grup turystycznych. Dzięki temu pomysłowi osoby wykluczone społecznie mogą odzyskać niezależność finansową oraz wrócić do pracy zawodowej. Jednocześnie turyści zyskują możliwość bardzo nieszablonowego poznania Lizbony.

\subsection{Stany Zjednoczone Ameryki Północnej (USA)}

Inicjatywy służące wdrażaniu założeń rozwoju zrównoważonego na obszarach chronionych w USA są wynikiem złożonych, wieloletnich programów i przyjętych strategii (np. działania związane z dostosowaniem 
i modernizacją infrastruktury) oraz inicjatyw podejmowanych przy zaangażowaniu znacznie mniejszych środków (w tym np. działalność edukacyjna czy wydawnicza). Jednym z najważniejszych programów regulujących rodzaje aktywności z zakresu rozwoju zrównoważonego pozostaje Projekt Green Parks. Wspieranie naszej misji poprzez zrózwnoważone działania (oryg. Green Parks Plan. Advancing Our Mission Through Sustainable Operations) (Majdak, 2014, 2017). Dokument został opublikowany w 2016 r. i ramowo określono w nim inicjatywy, cele i działania, które przedstawiono w tabeli 2.

Tabela 2. Cele strategiczne programu Green Parks Plan

\begin{tabular}{|c|l|l|}
\hline Lp. & \multicolumn{1}{|c|}{ Inicjatywa } & \multicolumn{1}{c|}{ Cele i działania } \\
\hline 1 & $\begin{array}{l}\text { Nieustannie poprawiaj } \\
\text { efektywność środowiskową }\end{array}$ & $\begin{array}{l}\text { National Park Service (NPS) wdroży wy- } \\
\text { znaczone normy środowiskowe oraz naj- } \\
\text { lepsze zrównoważone praktyki }\end{array}$ \\
\hline 2 & $\begin{array}{l}\text { Bądź przyjazny klimatowi } \\
\text { i przygotuj się na zmiany klimatu }\end{array}$ & $\begin{array}{l}\text { NPS zmniejszy emisję gazów cieplarnia- } \\
\text { nych i dostosuje obiekty zagrożone zmia- } \\
\text { nami klimatu }\end{array}$ \\
\hline 3 & Bądź inteligentny energetycznie & $\begin{array}{l}\text { NPS poprawi wydajność energetyczną } \\
\text { obiektów i zwiększy zależność od ener- } \\
\text { gii odnawialnej }\end{array}$ \\
\hline 4 & Rozsądnie gospodaruj wodą & NPS poprawi efektywność zużycia wody \\
\hline 5 & Zapewnij zielony transport & $\begin{array}{l}\text { NPS zmieni swoją flotę, pojawią się bar- } \\
\text { dziej ekologiczne metody transportu }\end{array}$ \\
\hline 6 & $\begin{array}{l}\text { Kupuj produkty naturalne, } \\
\text { zmniejszaj ilość odpadów, } \\
\text { używaj ponownie i odzyskuj }\end{array}$ & $\begin{array}{l}\text { NPS kupi nieszkodliwe dla środowiska } \\
\text { produkty i zwiększy ilość odpadów do } \\
\text { recyklingu }\end{array}$ \\
\hline 7 & $\begin{array}{l}\text { Wzmacniaj partnerstwo } \\
\text { na rzecz zrównoważonego rozwoju }\end{array}$ & $\begin{array}{l}\text { NPS włączy inicjatywy zrównoważone- } \\
\text { go rozwoju w nowe i istniejące partner- } \\
\text { stwa }\end{array}$ \\
\hline 8 & $\begin{array}{l}\text { Promuj zdrową aktywność } \\
\text { na świeżym powietrzu }\end{array}$ & $\begin{array}{l}\text { NPS będzie promować zdrową aktyw- } \\
\text { ność na świeżym powietrzu i minimali- } \\
\text { zować wpływ podejmowanych działań } \\
\text { na środowisko }\end{array}$ \\
\hline promuj zrównoważony rozwój & $\begin{array}{l}\text { NPSzaangażujeosoby zzewnątrzw zrów- } \\
\text { noważony rozwój i zaprosi je do współ- } \\
\text { pracy }\end{array}$ \\
\hline & $\begin{array}{l}\text { NPS podejmie działania na rzecz zrów- } \\
\text { noważonego rozwoju krajobrazów }\end{array}$ \\
\hline
\end{tabular}

Źródło: opracowanie własne na podstawie National Park Service U.S. Department of the Interior (2016). 
Oprócz wskazań zawartych w tab. 1 można wymienić wiele inicjatyw, które służą realizacji zawartych w niej założeń. Do najważniejszych należą (Conservation Measures, 2017):

- działalność edukacyjna i wydawnicza: podejmowanie działań służących upowszechnianiu wiedzy na temat zasobów naturalnych i kulturowych oraz konieczności ich ochrony;

- utrzymywanie zrównoważonej infrastruktury turystycznej (w tym miejsc noclegowych, zaplecza gastronomicznego, punktów usługowo-handlowych itp.), służącej z jednej strony udostępnianiu terenów wypoczynkowych, z drugiej natomiast kanalizowaniu ruchu turystycznego;

- prowadzenie lokalnych stacji radiowych dla zmotoryzowanych, a także innych serwisów informacyjnych (przekazywanie bieżących wiadomości dotyczących natężenia ruchu, sytuacji pogodowej, ewentualnych zagrożeń);

- wprowadzanie alternatywnych środków transportu (np. konie i muły), udostępnianie turystom ekologicznych autobusów, umożliwiających poruszanie się $\mathrm{w}$ obrębie obszarów chronionych, oddanie do użytku pojazdów ekologicznych;

- używanie energii odnawialnej (elektrownie wodne, wiatrowe, słoneczne);

- limitowanie wejść i wprowadzanie opłat za wstęp na teren obszaru chronionego;

- prowadzenie ekologicznej administracji (zmniejszenie zużycia materiałów biurowych, rezygnacja z przedmiotów jednorazowego użytku).

\section{Zakończenie}

Dzięki poruszanym $\mathrm{w}$ artykule zagadnieniom zostały przybliżone kwestie związane zarówno z kontekstem teoretycznym turystyki zrównoważonej, jak i wprowadzaniem w życie założeń tej koncepcji na obszarach przyrodniczo cennych, pełniących funkcje turystyczne.

Prezentowany katalog rozwiązań praktycznych obejmuje działania będące rezultatem rozbudowanych i długofalowych ogólnonarodowych projektów, jak również inicjatywy realizowane na poziomie lokalnym. Jednocześnie omówione rozwiązania uwidaczniają, że założenia rozwoju zrównoważonego stanowią źródło inspiracji do 
podejmowania działań praktycznych, prowadzonych na obszarach chronionych, a sama koncepcja nie ogranicza się jedynie do warstwy dyskursywnej i teoretycznej.

\section{Bibliografia}

Coccossis, H., Parpairis, A. (2000). Assessing the interaction between heritage, environment and tourism: Mykonos. W: H. Coccossis, P. Nijkamp (red.), Sustainable tourism development (s. 107-125). Aldershot Burlington-Singapore-Sydney: Ashgate.

Conservation Measures (2017). Pobrane z: https://www.nps.gov/yell/getinvolved/energyconservation.htm (2.04.2020).

Gołembski, G. (2002). Pojęcie i cele zintegrowanego zarządzania w regionach. W: G. Gołembski (red.), Kompendium wiedzy o turystyce (s. 368-384). Warszawa: Wydawnictwo Naukowe PWN.

Jalinik, M. (2009). Zarządzanie gospodarstwem ekoagroturystycznym na obszarach przyrodniczo cennych. Zeszyty Naukowe Politechniki Białostockiej, 14, 85-94.

Kassenberg, A. (2007). Zrównoważony rozwój a koncepcja przestrzennego zagospodarowania kraju. W: G. Gorzelak, A. Tucholska (red.), Rozwój, region, przestrzeń (s. 53-87). Warszawa: Ministerstwo Rozwoju Regionalnego.

Kowalczyk, A. (red.) (2010). Turystyka zrównoważona. Warszawa: Wydawnictwo Naukowe PWN.

Kozak, M.W. (2009). Turystyka i polityka turystyczna a rozwój: między starym a nowym paradygmatem. Warszawa: Scholar.

Majdak, P. (2014). Sustainable tourism in the selected US national parks. Practical solutions. Turystyka i Rekreacja, 2 (2), 59-63.

Majdak, P. (2017). Zrównoważona przestrzeń obszarów chronionych w Stanach Zjednoczonych Ameryki Północnej. Zarządzanie i rozwiązania praktyczne. W: M. Dębski, A. Jackiewicz (red.), Przedsiębiorczość i Zarzadzanie. T. XVIII (8/3): Region turystyczny - zarządzanie i rozwój. Narzędzia, metody, szanse, wyzwania, perspektywy (s. 329-344). Warszawa: Społeczna Akademia Nauk.

Majdak, P. (2019). Rozwój zrównoważony i innowacje w turystyce. Warszawa: Akademia Wychowania Fizycznego J. Piłsudskiego.

National Park Service U.S. Department of the Interior (2016). Green Parks Plan. Advancing Our Mission Through Sustainable Operations. Pobrane z: https://www.nps.gov/subjects/ sustainability/upload/NPS-Green-Parks-Plan-2016.pdf (2.04.2020).

Programa Nacional de Turismo de Natureza (2017). Pobrane z: https://www.icnf.pt/turismodenatureza/empreendimentos (20.10.2017).

Sustainable tourism. Pobrane z: http://www.portugalwalkhike.com/sustainable-tourism (2.04.2020).

Tefft, A., Thayer, R., Thomas, M. (1993). Guiding principles of sustainable design (in parks and other conservation areas). National Park Service, DIANE Publishing Company. Pobrane z: https://books.google.pl/books?id=XKas9nXGjlkC\&printsec $=$ frontcover\&hl=pl\# $\mathrm{v}=$ on epage\&q\&f=false (23.03.2020).

Stankey, G.H., Cole, D.N., Lucas, R.C., Petersen, M.E., Frissell, S.S. (1985). The Limits of Acceptable Change (LAC) system for wilderness planning. United States Department of Agriculture. 


\title{
TURYSTYKA ZRÓWNOWAŻONA NA OBSZARACH PRZYRODNICZO CENNYCH: KONTEKSTY TEORETYCZNE - STRATEGIE - ZASTOSOWANIA
}

\begin{abstract}
Abstrakt: Prezentowane w artykule rozważania skupiają się wokół problematyki rozwoju turystyki zrównoważonej na obszarach chronionych. Poruszane kwestie przybliżają zarówno teoretyczna, jak i praktyczną stronę zagadnienia rozwoju zrównoważonego. Analizom poddano rozmaite dokumenty, określające ramy funkcjonowania obszarów przyrodniczo cennych, jak i działania, które służą wdrażaniu przyjętych założeń. Zawarte w artykule analizy odnoszą się do dwóch krajów: Portugalii oraz Stanów Zjednoczonych Ameryki Północnej (USA). Wpływ na taki wybór miała różnorodność wynikająca z uwarunkowań przyrodniczych, geograficznych, przestrzennych oraz odmienność w sposobie zarządzania obszarami chronionymi wymienionych państw. Dzięki temu w proponowanym $\mathrm{w}$ artykule katalogu rozwiązań zaprezentowano szerokie spektrum działań, obejmujących zarówno inicjatywy wynikające z realizacji ogólnonarodowych projektów, jak i projekty realizowane na poziomie prywatnych firm czy lokalnych stowarzyszeń.
\end{abstract}

Słowa kluczowe: turystyka, rozwój zrównoważony, obszary chronione, strategie, zastosowania.

\section{SUSTAINABLE TOURISM IN VALUABLE NATURAL AREAS: THEORETICAL CONTEXTS - STRATEGIES - APPLICATIONS}

\begin{abstract}
The author focuses on the development of sustainable tourism in protected areas and the problems presented illustrate the theoretical as well as the practical side of such tourism. The analysis covers a range of documents which regulate the functioning of valuable natural areas, as well as defining the activities that serve to implement the assumptions that have been adopted. The analyses presented in the article concern two countries: Portugal and the United States of America. Their choice was determined by the differences between them resulting from their diverse natural, geographical, spatial conditions, as well as different methods of managing protected areas. The solutions proposed present a wide spectrum of activities including initiatives both originating from national projects and those run at the level of private firms or local associations.
\end{abstract}

Keywords: tourism, sustainable development, protected areas, strategies, applications. 